\title{
Natural killer cell activity in workers exposed to benzidine and $\beta$-naphthylamine
}

\author{
T Tanigawa, S Araki, S Ishizu, T Morita, H Okazaki, N Minato
}

\begin{abstract}
To investigate the effects of benzidine $(\mathrm{BZ})$ and $\beta$-naphthylamine (BNA) on the immune system in man, the activity of natural killer (NK) cells as well as the relative number (percentage) of Leu 11a positive cells in peripheral blood lymphocytes were measured in 63 dyestuff workers exposed to $B Z$ and BNA (aromatic amines, AA). The cytotoxic potential per NK cell (unit NK cell activity) was approximated by dividing the NK activity per fixed numbers of unseparated mononuclear cells by the percentage of Leu 11a positive lymphocytes that mediated NK activity. Thirty one of these workers had previously been treated for bladder cancer and then cured (excancer AA workers) whereas the remaining 32 had not been diagnosed as having bladder cancer (non-cancer AA workers). There was no significant difference in the gross $\mathrm{NK}$ activity per unseparated peripheral mononuclear cells among ex-cancer $A A$ workers, non-cancer $A \dot{A}$ workers, and the control group ( $p>0.05)$. The relative number of Leu 11 a positive cells, on the other hand, was significantly higher in AA workers than in the control group $(p<0.01)$. The unit NK cell activity, as a result, was significantly more reduced in both ex-cancer and non-cancer $A A$ workers than in the control group ( $p<0.05$ and $p<0.01$, respectively). Between ex-cancer and non-cancer AA workers, no significant difference was observed in terms of unit NK cell activity. These results indicated that the function of NK cells per se was impaired in $A A$ workers
\end{abstract}

Department of Public Health, Faculty of Medicine, University of Tokyo, Hongo, Bunkyoku, Tokyo 113, Japan

T Tanigawa, S Araki

Occupational Health Service Center, Shiba, Minatoku, Tokyo 108

$S$ Ishizu

Jichi Medical School, Minami-Kawachi, Kawachigun, Tochigi 329-04

Department of Urology

T Morita

Department of Medicine, Division of Clinical Immunology

H Okazaki, N Minato whereas the number of circulating NK cells was relatively increased.

It has been established that workers exposed to benzidine (BZ) and $\beta$-naphthylamine (BNA) have a greatly increased risk of developing bladder cancer. ${ }^{12}$ The number of people who are at high risk for bladder cancer due to occupational exposure to aromatic amines (AA) amounts to more than 6000 in the United States, ${ }^{3} 3000$ in Japan (Ad hoc committee on industrial hygiene of the Japan Dyestuff Industry Association), and 2500 in China. ${ }^{4}$ Therefore, management of asymptomatic workers at high risk for bladder cancer is still important.

In 1956 Crabbe et al reported the usefulness of the Papanicolaou test that since then has been widely used to detect occupational bladder cancer. ${ }^{5}$ The Papanicolaou test, however, is effective only after cancer has fully developed since only then are abnormal cells observed by microscopy. In 1979 Kumar et al reported a new test, in which the killing activity of lymphocytes against a bladder cancer cell was examined in workers at risk. ${ }^{67}$

In recent years many findings indicate that natural killer (NK) cells have an important role in inhibiting tumourigenesis. NK cells are a population of lymphocytes with the capability to lyse a variety of aberrant cells independent of the major histocompatibility complex. ${ }^{89}$ In patients with bladder cancer the function of NK cells has been reported to be impaired but the occupational background of the patients was not described ${ }^{10}$ (and T Morita et al, unpublished data). At present, there is no systemic report on NK function in workers at a high risk for bladder cancer. In the present study we measured the activity and relative number of NK cells in workers exposed to BZ and BNA.

\section{Subjects}

The 63 male subjects were retired or currently employed factory workers; all had been exposed to BZ or BNA (aromatic amines, AA) before 1972. Thirty one, aged 54 to 70 (mean 62), had been previously treated for bladder cancer and cured (excancer AA workers). The remaining 32 aged 43 to 69 (mean 58) had not been diagnosed as having bladder cancer (non-cancer AA workers). The control group consisted of 33 "healthy" male volunteers aged 42 to 
64 (mean 54) who were working at the same factory but without a history of occupational exposure to $\mathrm{BZ}$ and BNA.

No subject had signs and symptoms indicative of infection at the time of the study; none had used drugs that could affect immunological analysis. There were nine, 16, and 15 smokers in the excancer, non-cancer, and control groups respectively; the proportion of smokers did not statistically differ among the three groups. According to several investigators, there is no significant relation between NK cell activity and the age of these ranges in human adults. ${ }^{112}$ Therefore, the difference in age among the three groups was not considered to be a confounding variable.

\section{Methods}

The procedure was explained to all subjects and this study was conducted with their informed consent.

Mononuclear cells were separated from heparinised peripheral blood by Ficoll-Conray density gradient centrifugation, washed twice with phosphate buffered saline, and resuspended in PRMI 1640 medium supplemented with $10 \%$ fetal calf serum (FCS).

NK cell activity was determined by ${ }^{51} \mathrm{Cr}$ release assay, ${ }^{13}$ using mononuclear cells as effector cells and the human chronic myeloid leukaemia derived cell line, $\mathrm{K} 562$, as target cells. Target cells $\left(2 \times 10^{6}\right)$ were labelled with $3.7 \mathrm{MBq}$ of sodium chromate $\left(\mathrm{Na}_{2}{ }^{51} \mathrm{CrO}_{4}\right)$ (New England Nuclear, Boston, Massachusetts) for two hours at $37^{\circ} \mathrm{C}$ in humidified $5 \% \mathrm{CO}_{2}$ in air. The cells were then washed three times and resuspended at $1 \times 10^{5} / \mathrm{ml}$ in $10 \%$ FCSRPMI 1640 medium. Aliquots $(100 \mu \mathrm{l})$ of target cells were mixed with $100 \mu \mathrm{l}$ of effector cell suspensions in round bottomed 96 well microculture plates to give effector:target (E:T) ratios at 5:1, 10:1, 20:1, and 40:1 in triplicate. The plates were incubated for four hours. From each well $100 \mu \mathrm{l}$ of supernatant were removed and counted on a gamma counter. The spontaneous ${ }^{51} \mathrm{Cr}$ release, determined by incubating labelled target cells in the medium alone, did not exceed $15 \%$ of the maximal release that was determined by adding $1 \%$ Triton X-100 (Sigma Chemical Co, St Louis, MO). The per cent specific cytolysis was calculated as follows: per cent specific cytolysis $=$ (experimental ${ }^{51} \mathrm{Cr}$ release - spontaneous ${ }^{51} \mathrm{Cr}$ release)/(maximal ${ }^{51} \mathrm{Cr}$ release - spontaneous ${ }^{51} \mathrm{Cr}$ release) $\times 100$. The mean per cent specific cytolysis obtained at each E:T ratio was plotted against the logarithm of the $\mathrm{E}: \mathrm{T}$ ratio and a linear dose response curve was obtained with a least squares fit method. ${ }^{14}$ We defined one lytic unit (LU) as the number of effector cells needed to achieve $33.3 \%$ cytolysis of $10^{4}$ target cells which was obtained from the doseresponse curve. To evaluate the NK activity per whole mononuclear cells, the number of lytic units in
$10^{7}$ effector cells (LUs $/ 10^{7}$ cells) was calculated.

For direct immunofluorescence staining, $2 \times 10^{6}$ mononuclear cells were incubated with $15 \mu \mathrm{l}$ of FITC conjugated monoclonal anti-Leu $11 \mathrm{a}$ antibody (Becton Dickinson, Mountain View, California) on ice for 30 minutes, washed twice with RPMI 1640, and resuspended in 10\% FCS-RPMI 1640. All samples were then analysed for immunofluorescence on a flowcytometer (EPICS CS, Coulter Electronics, Hialeah, FL). Non-lymphocytic cells contaminating the preparations were excluded from analysis using scatter gates set on the $90^{\circ}$ and straight light scatter profile. Ten thousand lymphocytes were analysed for each sample and the number of fluorescinated cells were expressed as a percentage of the total lymphocytes. Anti-Leu 11a antibody is thought to detect those cells that have a high degree of NK cell activity. ${ }^{15} 16$

To approximate the cytotoxic activity per one NK cell, we defined the "unit NK cell activity" by dividing the LUs $/ 10^{7}$ cells by percentage of Leu 11a positive lymphocytes.

Owing to the non-Gaussian distribution, all data were analysed statistically by the Wilcoxon rank sum test.

\section{Results}

The results of NK activity per whole peripheral mononuclear cells are summarised among ex-cancer AA workers, non-cancer AA workers, and the control group (table). There was no statistically significant difference among the three groups. It was noted, however, that the degree of individual variability was high in the AA workers as compared with the control group. Thus the control group had a range of NK activity per whole peripheral mononuclear cells between 3.7 and $104 \mathrm{LUs} / 10^{7}$, whereas six ex-cancer and seven non-cancer AA workers were outside this range. We then analysed the relative proportions of Leu 11 a positive lymphocytes that actually mediated cytotoxic activity in the same groups. The proportions of Leu 11a positive cells in peripheral lymphocytes in AA workers were significantly higher than that in the control group (fig 1). Between excancer and non-cancer AA workers, however, no

Natural killer (NK) cell activity per whole mononuclear cells

\begin{tabular}{|c|c|c|c|}
\hline & \multirow[b]{2}{*}{ No of subjects } & \multicolumn{2}{|c|}{$N K$ cell activity ( $L U s / 10^{7}$ cells) } \\
\hline & & Mean & Range \\
\hline $\begin{array}{l}\text { Ex-cancer } \\
\text { AA workers } \\
\text { Non-cancer }\end{array}$ & 31 & $43 \cdot 7$ & $0.03 \sim 177$ \\
\hline $\begin{array}{l}\text { AA workers } \\
\text { Control group }\end{array}$ & $\begin{array}{l}32 \\
33\end{array}$ & $\begin{array}{l}20 \cdot 1 \\
47 \cdot 1\end{array}$ & $\begin{array}{l}0.5 \sim 269 \\
3.7 \sim 104\end{array}$ \\
\hline
\end{tabular}

$\mathrm{LU}=$ Lytic unit. Mean $=$ Median value. $\mathrm{AA}=$ Aromatic amines. 


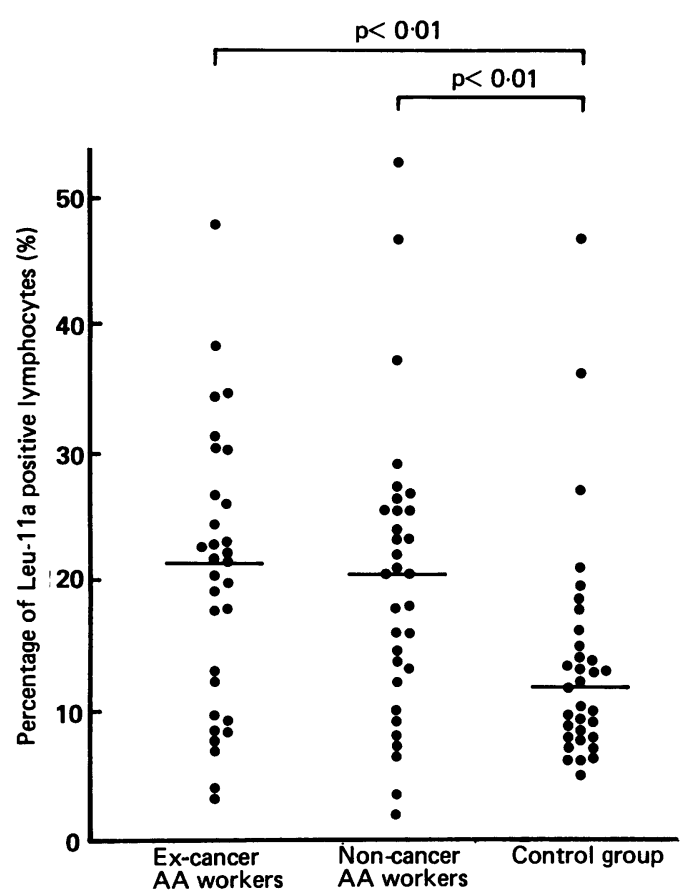

Figure 1 Relative number of natural killer (NK) cells in lymphocytes identified by monoclonal antibody Leu 11 a. Each point represents one subject. Transverse line indicates median.

difference was observed at all. Based on these results, unit NK cell activity was calculated in every individual. As is evident, both ex-cancer and noncancer AA workers showed significantly reduced unit NK cell activity as compared with the control group (fig 2).

\section{Discussion}

No significant difference was found in the NK cell activity per whole mononuclear cells among ex-cancer AA workers, non-cancer AA workers, and the control group. The proportion of Leu 1la positive cells in the lymphocytes, on the other hand, was significantly higher in both ex-cancer and non-cancer AA workers than in the control group. These results suggested that both ex-cancer and non-cancer AA workers had significantly reduced cytotoxic activity per one NK cell. It remains to be discovered whether the increased proportion of peripheral Leu 11 a positive cells in AA workers is due to the increase in absolute number of Leu 11 a positive cells or to the decrease in other lymphocyte subsets such as $T$ lymphocytes. Interestingly, it was reported by Jennings $e t$ al that the number of Leu 11a positive cells was also increased in workers exposed to dioxin 17 years before the study, although NK activity was not studied in the report. ${ }^{16}$ In either case it seems

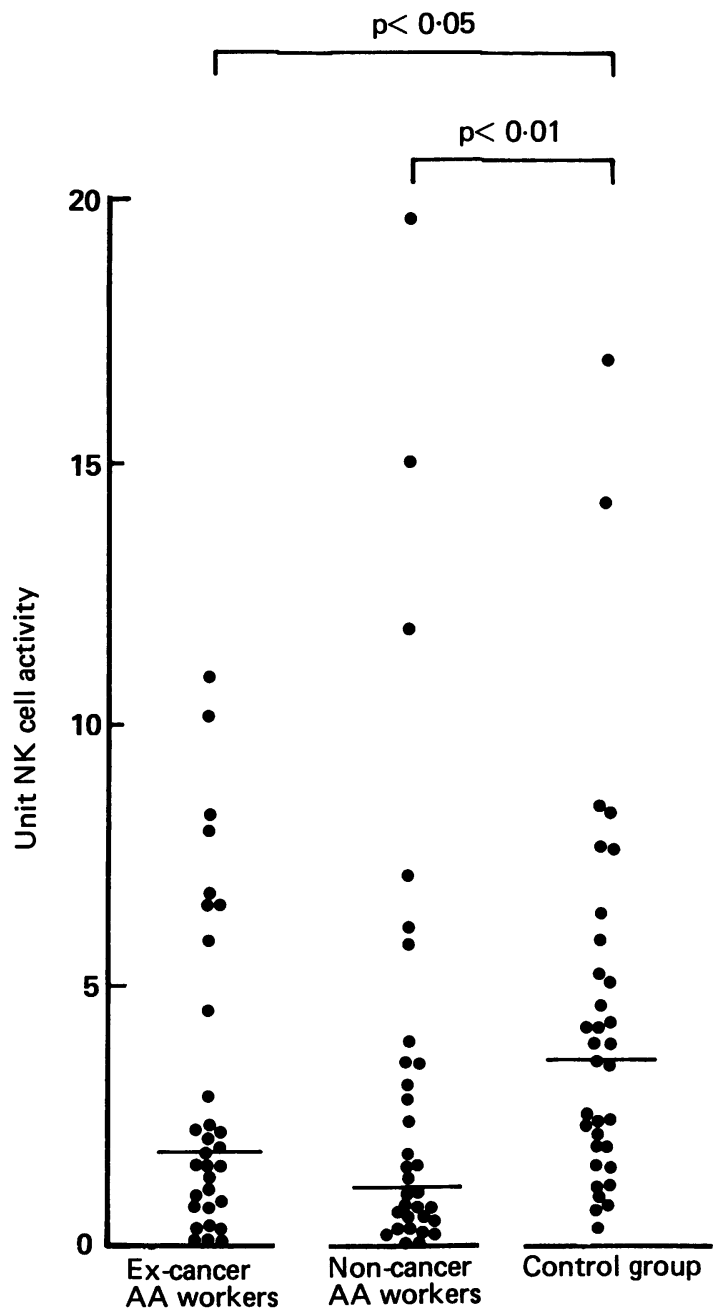

Figure 2 Unit natural killer (NK) cell activity. Each point represents one subject. Transverse line indicates median.

conceivable that the reduced cytolytic capacity of each NK cell is somehow compensated by the relative increase in the number of circulating NK cells, thus maintaining the NK activity as a whole peripheral pool in AA workers. It was particularly noted that there was no significant difference in the unit NK cell activity between ex-cancer and non-cancer group of AA workers, suggesting that the reduction of the unit NK cell activity was primarily due to the exposure to AA per se rather than to the history of cancer. In patients with overt bladder cancer it had already been reported that the NK cell activity was greatly reduced $^{10}$ despite the relative increase in Leu 11a positive cells ( $\mathrm{T}$ Morita et al.) Thus the present observation in cancer free AA workers-namely, the reduced unit NK cell activity with apparently normal 
range of NK cell activity per whole mononuclear cells-might be considered as a characteristic feature of the high risk population.

Kumar et al reported that the lymphocytes in workers exposed to $\alpha$-naphthylamine, $\beta$-naphthylamine, and benzidine had an increased killing activity to bladder cancer cell line. ${ }^{78}$ The assay conditions in their study, however, differed from ours in the cytotoxicity assay time (four $v \mathbf{4 0}$ hours) and target cells (K562 $v$ bladder cancer cell). Our present assay system primarily detects NK activity whereas theirs may well include cytotoxic activity of other effector cells than NK cells such as macrophages and $T$ lymphocytes.

The mechanism for the altered lytic activity and proportion of NK cells in AA workers are totally unknown. It seems rather mysterious that such immunological alterations persist in workers who ceased to be exposed to carcinogenic chemicals nearly 20 years ago. This may imply either that the trace chemicals persisted in the body for years or that the effect was on the progenitor lymphoid cells with a self renewal potential. In a practical sense the present results show that the proportion of Leu 11a positive cells rather than gross $\mathrm{NK}$ activity provided a much more sensitive index to reflect immunological alterations in AA workers. This assay also has an advantage in that the proportion may be quantitatively and reproducibly determined by a flowcytometric analysis as compared with sensitive bioassay such as NK assay. We hope that the measurement of Leu 11a positive cells may turn out to be a helpful marker for the follow up of workers exposed to carcinogenic chemicals such as AA and dioxin.

We thank Ms Y Saikai and Ms M Okamoto for technical help.

Requests for reprints to Professor S Araki.
1 Case RAM, Hosker ME, McDonald DB, Pearson JT. Tumours of the urinary bladder in workmen engaged in the manufacture and use of certain dyestuff intermediates in the British chemical industry; the role of aniline, benzidine, alpha-naphthylamine, and beta-naphthylamine. Br J Ind Med 1954; 11:75-104.

2 Tsuchiya K, Okubo T, Ishizu S. An epidemiological study of occupational bladder tumours in the dye industry of Japan. $B r$ $J$ Ind Med 1975;32:203-9.

3 Schulte PA, Ringen K, Hemstreet GP. Optimal management of asymptomatic workers at high risk of bladder cancer. $J$ Occup Med 1986;28:13-7.

$4 \mathrm{Wu}$ W. Occupational cancer epidemiology in the People's Republic of China. J Occup Med 1988;30:968-74.

5 Crabbe JGS, Cresdee WC, Scott TS, Williams MHC. The cytological diagnosis of bladder tumours amongst dyestuff workers. $\mathrm{Br} J$ Ind $\mathrm{Med}$ 1956;13:270-6.

6 Taylor G, Kumar S, Brenchley P, Wilson P, Costello B, Shaw GH. Immunosurveillance in pre-malignant occupational bladder disease. Int J Cancer 1979;23:487-93.

7 Kumar S, Taylor G, Wilson P, Hurst W. Prognostic importance of specific immunoreactivity in occupational bladder cancer. Br Med J 1980;280:512-3.

8 Bloom BR. Natural killers to rescue immune surveillance? Nature 1982;18:214-5.

9 Minato N. Natural killer cells: characteristics and their role in antitumor resistance. In: Hashimoto $Y$, Hamaoka $T$, eds Gann monograph on cancer research. (No 34: Cellular and molecular mechanisms of tumor immunity). Tokyo: Japan Scientific Societies Press, 1988:99-110.

$10 \mathrm{Ma} \mathrm{CP}$, Yu DS, Yeh MY, Chang SY, Han SH. Natural killer cell activity in patients with urologic cancer. Eur Urol 1987;13:397-400.

11 Onsrud M. Age dependent changes in some human lymphocyte sub-populations. Acta Pathol Microbiol Immunol Scand sect C 1981;89:55-62.

12 Herberman RB, Holden HT. Natural cell-mediated immunity. Adv Cancer Res 1978;27:305-77.

13 Minato N, Takeda A, Kano S, Takaku F. Studies of the functions of natural killer-interferon system in patients with Sjögren syndrome. J Clin Invest 1982;69:581-8.

14 Cerottini JC, Brunner KT. In vitro assay of target cell lysis by sensitised lymphocytes. In: Bloom BR, Glade PR, eds. In vitro methods in cell-mediated immunity. New York: Academic Press, 1971:369-73.

15 Lanier LL, Le AM, Phillips JH, Warner NL, Babcock GF. Subpopulations of human natural killer cells defined by expression of the Leu-7 (HNK-1) and Leu-11 (NK-15) antigens. J Immunol 1983;131:1789-96.

16 Jennings $A M$, Wild $G$, Ward JD, Ward AM. Immunological abnormalities 17 years after accidental exposure to $2,3,7,8$ tetra chlorodibenzo-p-dioxin. Br J Ind Med 1988;45:701-4.

Accepted 14 August 1989 